\title{
Influence of Sulphur Impurities on the Interfacial Tension between Aluminium and Cryolite Alumina Melts
}

\author{
Michal Korenko \\ Department of Inorganic Chemistry, Slovak Academy of Sciences, Dubravska cesta 9, \\ SK-845 36 Bratislava, Slovakia \\ Reprint requests to M. K.; E-mail: uachmiko@savba.sk \\ Z. Naturforsch. 62a, 309 -314 (2007); received February 9, 2007 \\ Presented at the EUCHEM Conference on Molten Salts and Ionic Liquids, Hammamet, Tunisia, \\ September 16-22, 2006. \\ The interfacial tension (IFT) between aluminium and cryolite melts containing different salt addi- \\ tions $\left(\mathrm{AlF}_{3}, \mathrm{NaF}, \mathrm{Na}_{2} \mathrm{SO}_{4}\right)$ has been measured during electrolysis by the capillary depression method. \\ The technique is based on the measurement of the capillary depression occurring when a capillary, \\ which is moved vertically down through the molten salt layer, passes through the metal/salt interface. \\ The depression is measured by simultaneous video recording of the immersion height of the alumina \\ capillary. The interfacial tension is strongly dependent on the $n(\mathrm{NaF}) / n\left(\mathrm{AlF}_{3}\right)$ ratio. The addition of \\ $\mathrm{Na}_{2} \mathrm{SO}_{4}$ decreases the IFT of the aluminium/electrolyte interface. We also found the different influ- \\ ence of the conditions of electrolysis on the IFT in systems with and without $\mathrm{Na}_{2} \mathrm{SO}_{4}$. In systems \\ without $\mathrm{Na}_{2} \mathrm{SO}_{4}$ the IFT decreases with increasing current density, and in systems with $\mathrm{Na}_{2} \mathrm{SO}_{4}$ it \\ increases.
}

Key words: Interfacial Tension; Cryolite; Sulphur Impurities; Aluminium Electrolysis.

\section{Introduction}

In the Hall-Héroult cell for electrolysis of alumina, the interfacial tension (IFT) between aluminium and the electrolyte influences the stability and shape of the interface which, in turn, may control the rate of back dissolution of aluminium into the electrolyte. It is now generally accepted that the loss in current efficiency is mainly controlled by the rate of dissolution of aluminium into the bath phase [1,2]. Thus, all factors which affect the bath/metal boundary will influence the current efficiency.

As indicated by Grjotheim et al. [1] and Thonstad et al. [2], information concerning the effect of electrolysis on the IFT is limited. The IFT between aluminium and cryolite melts has previously been investigated mostly by the Russian authors Zhemchuzhina and Belyaev [3], Gerasimov and Belyaev [4], Portevin and Bastien [5], and Belyaev [6]. Later, investigations were carried out by Dewing and Desclaux [7], Utigard and Toguri [8, 9], Grjotheim et al. [10], Fan and Østvold [11], and Korenko and Ondercin [12].

Sulphur as impurity is subject of extensive scientific and technologic interest, partly due to its role in the erosion of the carbon anodes, partly due its role related to the emission of $\mathrm{SO}_{2}, \mathrm{COS}, \mathrm{CS}_{2}$ and $\mathrm{H}_{2} \mathrm{~S}$ (the ratios in modern aluminium plants are $1.2 \mathrm{t} \mathrm{SO}_{2} / 100 \mathrm{t} \mathrm{Al}$ and $65-140 \mathrm{~kg} \mathrm{COS} / 100 \mathrm{t} \mathrm{Al}[13,14])$.

Sulphur in the process originates mainly from two sources. Petroleum coke used for the production of carbon anodes contains $0.7-4 \mathrm{wt} \%$ of sulphur. Cryolite and aluminium fluoride also contain sulphur, mainly as sulphates (up to 1\%). Sulphur leaves the aluminium cell mainly as $\mathrm{SO}_{2}$, with minor amounts of $\mathrm{COS}, \mathrm{CS}_{2}$ and $\mathrm{H}_{2} \mathrm{~S}[13,15,16]$.

The chemistry of sulphates in cryolite-based melts has been discussed mainly by Russian authors $[17,18]$. However, in most cases these considerations were not based on experimental data. Later, the topic was critically reinvestigated by Fellner et al. [16]. According to these works we can conclude that sulphur in the form of $\mathrm{SO}_{4}^{2-}$ is reduced by aluminium and carbon to $\mathrm{S}^{2-}$ and polysulfide species, which are probably the only form of sulphur impurities in molten cryolite $[14,16,19]$ :

$$
\begin{aligned}
& 3 \mathrm{Na}_{2} \mathrm{SO}_{4}(\mathrm{l})+2 \mathrm{Na}_{3} \mathrm{AlF}_{6}(\mathrm{l})+8 \mathrm{Al}(\mathrm{l}) \\
& \rightarrow 12 \mathrm{NaF}(\mathrm{l})+4 \mathrm{Al}_{2} \mathrm{O}_{3}(\mathrm{~s})+\mathrm{Al}_{2} \mathrm{~S}_{3}(\mathrm{~s}), \\
& \Delta_{\mathrm{r}} G_{1283 \mathrm{~K}}^{\mathrm{o}}=-3103 \mathrm{~kJ} \mathrm{~mol}^{-1},
\end{aligned}
$$




$$
\begin{aligned}
& 3 \mathrm{Na}_{2} \mathrm{SO}_{4}(\mathrm{l})+2 \mathrm{Na}_{3} \mathrm{AlF}_{6}(\mathrm{l})+3 \mathrm{C}(\mathrm{s}) \\
& \rightarrow 12 \mathrm{NaF}(\mathrm{l})+\mathrm{Al}_{2} \mathrm{O}_{3}(\mathrm{~s})+3 \mathrm{SO}_{2}(\mathrm{~g})+3 \mathrm{CO}(\mathrm{g}), \\
& \Delta_{\mathrm{r}} G_{1233 \mathrm{~K}}^{\mathrm{o}}=-173 \mathrm{~kJ} \mathrm{~mol}^{-1}
\end{aligned}
$$

Burnakin et al. [20,21] mentioned that, according to electrochemical studies, sulphur species can take part in the anode reactions. This opinion was supported by works of Gul'din and Buzhinskaya [22], Ambrová et al. [23] and Ambrová [24]. Gilmore and Bullough [25] also reported that the content of sulphur in prebaked anodes had a negative influence on the performance of cells.

It can be expected, against this background, that a high content of sulphur in the electrolyte can reduce the current efficiency of the process by competitive electrochemical side reactions at the anode. However, LaCamera's work [26] reported a decrease of the current efficiency in aluminium electrolysis with inert anodes in the presence of sulphur impurities also through decreasing the IFT at the metal/electrolyte interface. On the basis of previous facts it is very interesting to study the behaviour of sulphur near the cathode and the possible influence of sulphur on the IFT.

In this paper we study the influence of sulphur impurities (represented by the addition of $\mathrm{Na}_{2} \mathrm{SO}_{4}$ to molten cryolite) on the IFT between liquid aluminium and molten cryolite alumina electrolyte under conditions of electrolysis with graphite anodes.

\section{Experimental}

\subsection{Method and Experimental Apparatus}

The method used for interfacial tension measurements in this work is based on the capillary depression phenomenon, which takes place when a tube that is not wetted by a metallic phase is moved through the aluminium/melt interface. This method was used to measure the aluminium/cryolite interfacial tension by Dewing and Desclaux [7], and it is based on measuring the position of the metal/salt interface in the tube. By connecting the capillary tube to a horizontal glass tube, in which there is a liquid meniscus, the position of the metal/salt interface can be determined, based on the movement of this meniscus. As the sinter-corundum tube is moved down through the salt layer before reaching the metal interface, the molten salt entering the tube displaces a certain volume of gas (Fig. 1a). Since the tube is not wetted by the metal,

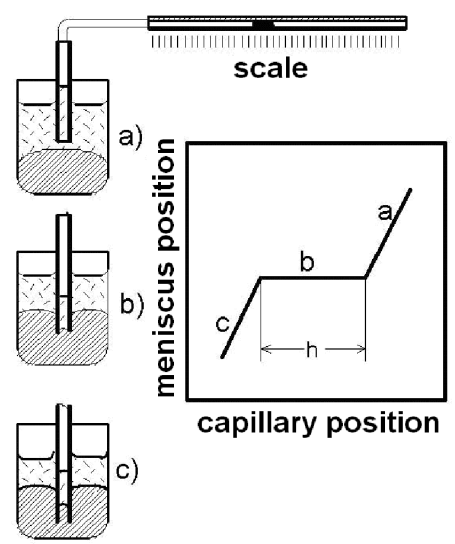

no metal will enter the tube as it reaches and passes through the metal/salt interface, and as long as the tube immersion is less than the capillary depression. Therefore, during this period there is no further displacement of the gas within the tube (Fig. 1b). However, as the tube is pushed further down until the maximal capillary depression is reached, metal starts to enter the tube, and again gas is displaced from the tube (Fig. 1c).

This technique has the disadvantage that, as the capillary tube moves down into the crucible, the average temperature inside the tube increases, leading to gas expansion and movement of the measuring meniscus. Dewing and Desclaux [7] tried to avoid this problem by moving the capillary rapidly to a certain immersion and then measuring the distance traveled by the meniscus during its initial rapid movement, assuming that the gas expansion will be reflected by a subsequent slower movement of the meniscus. By immersing the capillary tube to various depths, they were able to obtain a rough curve of the meniscus movement versus the depth of capillary immersion, which allowed them to determine the capillary depression. Since the movement of the meniscus was measured visually, personal judgment had to be applied as to when the rapid movement of the meniscus had ceased. One advantage of this method is that the ceramic tubes, such as alumina, are not wetted by most metals and are nearly inert in most low temperature molten salts. Another advantage is that the metal and the salt can be kept in contact long enough before the start of the interfacial tension measurement, allowing chemical equilibrium to be reached. Because of these advantages, we developed a revised and improved version of this technique, which was first presented by Silný and Utigard [27]. Video recording equipment and a PC are used for the 


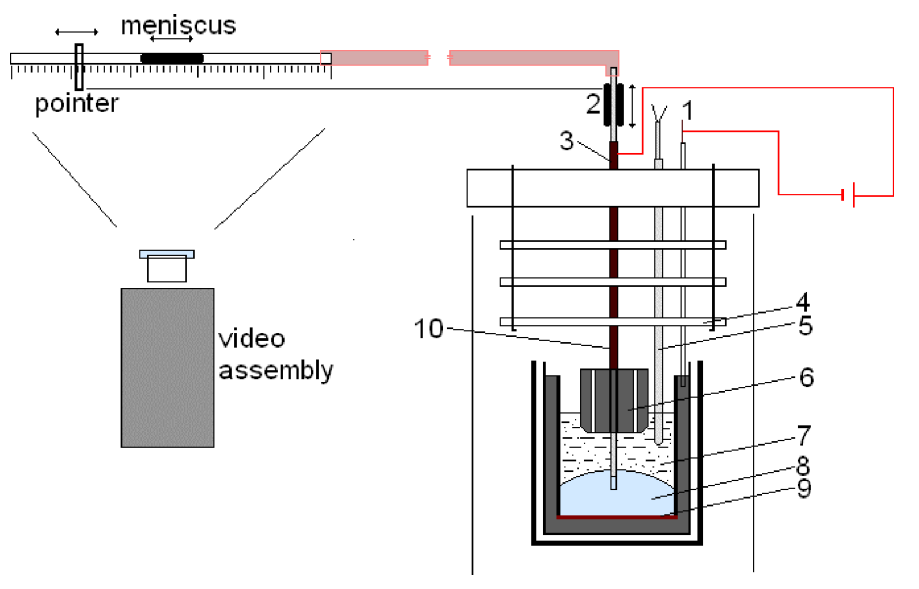

Fig. 2. Schematic representation of the experimental setup. 1, Cathode connection; 2, positioning device; 3 , anode connection; 4, radiation sheets; 5 , thermocouple; 6 , graphite anode; 7 , electrolyte; 8 , aluminium; 9 , mo plate; 10 , alumina tube for depression measuring.

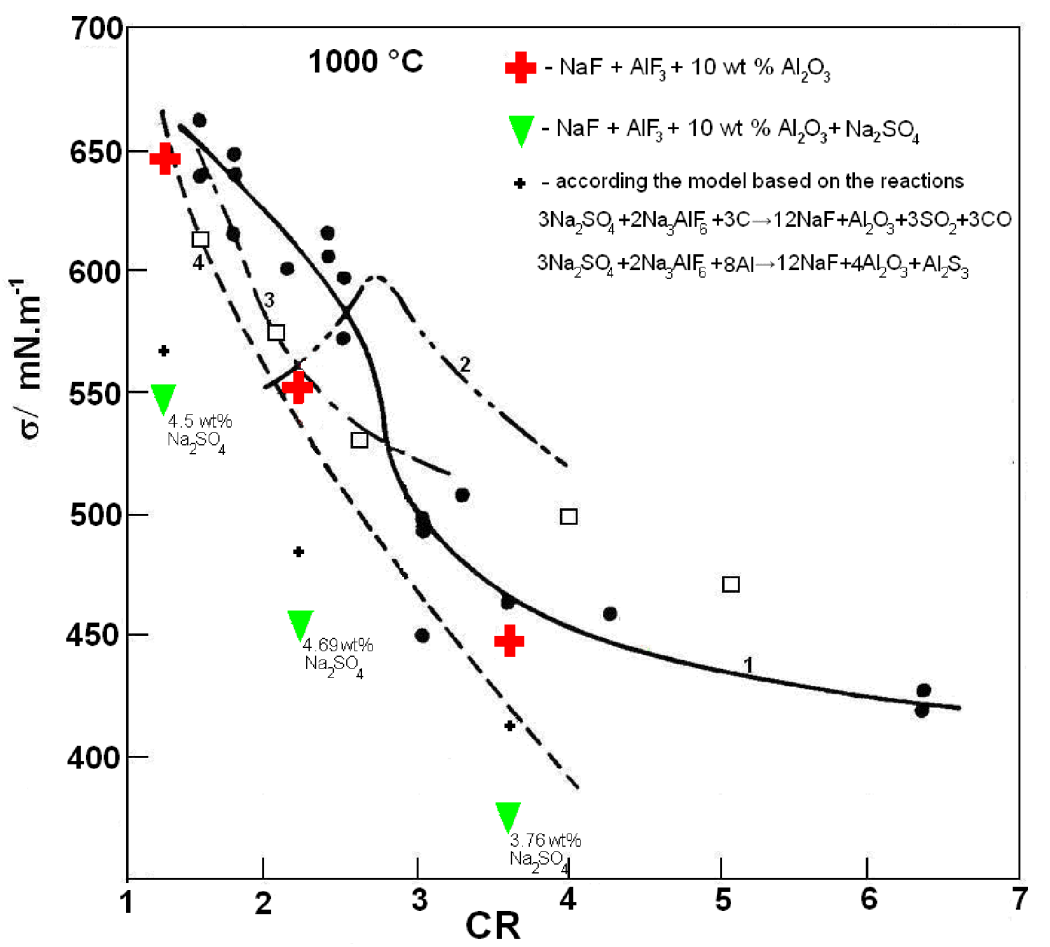

Fig. 3. Interfacial tension of aluminium in cryolite melts as a function of the cryolite ratio (CR). 1, Data of [9]; 2, data of [3]; 3, data of [4]; 4, data of [7]; $\square$, data of $[11] ; \mathbf{\nabla}, \mathbf{+},+$, present study. exact measurement of the interfacial tension between aluminium and molten salts.

A schematic diagram of the experimental setup is given in Figure 2. The measuring alumina capillary tube has an ID of $4.9 \mathrm{~mm}$, the OD is $7.2 \mathrm{~mm}$, and is connected via a plastic tube to the $2.5 \mathrm{~mm}$ ID horizontal glass tube containing the meniscus liquid. The measuring alumina tube was placed inside the anode connection tube. This connection tube was made of stainless steel, and at the end of this tube the graphite anode was placed. The anode was made from very pure graphite. The measuring alumina tube thus moves through the connection tube and anode. Such an assembly enables measuring of the capillary depression during the electrolysis.

Because an inert atmosphere was used, the furnace compartment was hermetically closed, allowing evacuation followed by refilling with argon. A gas buffer made from a flexible polyethylene bag provided pressure equalization between the reaction tube and the surroundings, allowing operation with slight overpressure inside during periods when no measurements 


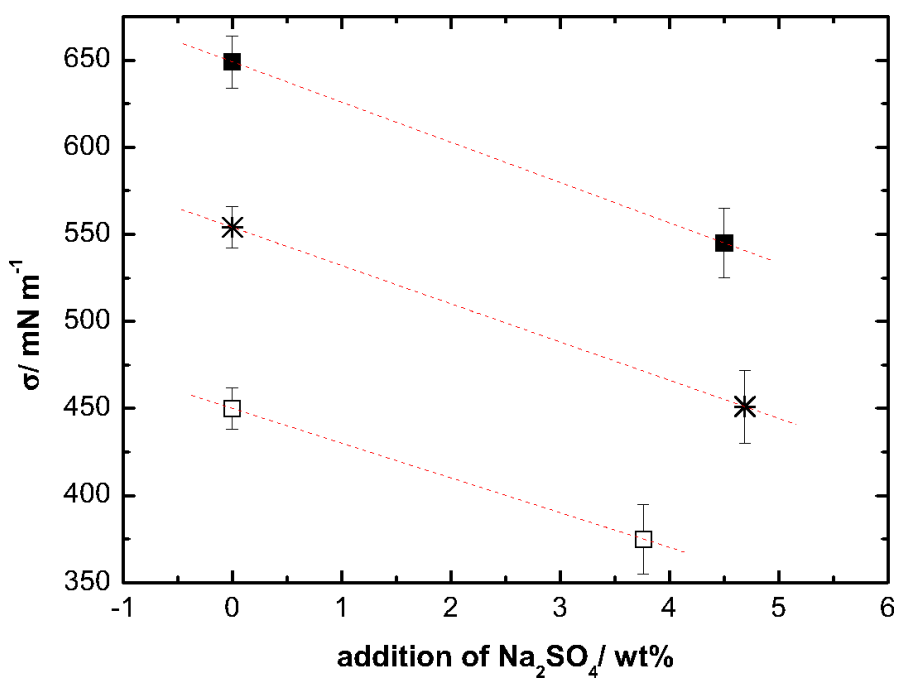

Fig. 4. Influence of $\mathrm{Na}_{2} \mathrm{SO}_{4}$ on the interfacial tension of $\mathrm{Na}_{3} \mathrm{AlF}_{6}+\mathrm{AlF}_{3}(\mathrm{NaF})+10 \mathrm{wt} \%$ $\mathrm{Al}_{2} \mathrm{O}_{3}+\mathrm{Na}_{2} \mathrm{SO}_{4} / \mathrm{Al}, t=1000{ }^{\circ} \mathrm{C}$. $\mathbf{\square}, \mathrm{CR}=1.37$; $*, \mathrm{CR}=2.29 ; \square, \mathrm{CR}=3.63$; all curves are linear formal lines. were taken. Further details of the technique and calculation procedure may be found in [27].

\subsection{Materials}

The chemicals used were as follows: Aluminium: HiChem Ltd. (Czech Republic), shots, min. 99.99\% purity, max. content of $\mathrm{Mg}$ : $40 \mathrm{ppm}, \mathrm{Si}: 15 \mathrm{ppm}, \mathrm{Cu}$ : 20 ppm, Fe, Mn, Cr, Ti, Zn: 5 ppm. Graphite: Elektrokarbon Ltd. (Slovakia), very pure. $\mathrm{Na}_{3} \mathrm{AlF}_{6}$ : Greenland, handpicked, dried at $300{ }^{\circ} \mathrm{C} . \mathrm{AlF}_{3}$ : resublimated, purity min. $99.5 \%$. NaF: Merck p. a., dried at $250{ }^{\circ} \mathrm{C}$. $\mathrm{Al}_{2} \mathrm{O}_{3}$ : Merck p.a., dried at $300{ }^{\circ} \mathrm{C}$. $\mathrm{Na}_{2} \mathrm{SO}_{4}$ : Merck p. a., dried at $300{ }^{\circ} \mathrm{C}$.

The preparation of the samples was carried out in a dry-box filled with high purity nitrogen. Graphite crucibles with 49-50 mm ID and height of $80 \mathrm{~mm}$ were used. The amounts of aluminium and salt were chosen so that after melting there was a $30 \mathrm{~mm}$ layer of aluminium and a molten salt layer of $30 \mathrm{~mm}$ in the crucible. The reaction tube was closed by a watercooled brass head, through which the measuring capillary, thermocouple and sampling tube could be immersed.

\section{Result and Discussion}

Figure 3 summarizes the data (no applied current) of the IFT in cryolite systems as a function of the cryolite ratio $(\mathrm{CR}) n(\mathrm{NaF}) / n\left(\mathrm{AlF}_{3}\right)$. The data from this work (data without $\mathrm{Na}_{2} \mathrm{SO}_{4}$ ) agree well mostly with Dewing and Desclaux [7]. In Figs. 3 and 4 the strong negative influence of addition of $\mathrm{Na}_{2} \mathrm{SO}_{4}$ on the IFT of the alumina/electrolyte interface can also be seen. The quantification of this influence is decreasing of the IFT by $100 \mathrm{mN} \mathrm{m}^{-1}$ (ca. 18\%) upon addition of ca. $4 \mathrm{wt} \%$ of $\mathrm{Na}_{2} \mathrm{SO}_{4}$.

On the basis of the observed data, the negative influence of sulphur, in high concentrations, on the current efficiency in the Hall-Héroult process can be expected. Sulphur can decrease the current efficiency not only by side competitive electrochemical reactions on anodes, like it is reported in [20-24], but also by decreasing of the IFT of the metal/electrolyte interface.

The decreasing of the IFT in sulphur-containing systems can be partially explained according the following model. It is generally accepted [1, 2, 7-12] that the IFT in the cryolite melts is strongly dependent on the $\mathrm{CR}$. Introduction of the sulphate species to the cryolite melts leads to formation of sulfides and $\mathrm{NaF}$ species according the reactions (1) and (2). The result of these reactions is the increase of the $\mathrm{CR}$ in the melt, and thereafter the decrease of the IFT between aluminium and melt. The both reactions are experimentally evidenced [16] (at least qualitatively). Figure 3 shows the calculated data of the IFT according to this model ( $100 \%$ conversion). It has to be mentioned, however, that the calculated data are shifted against the experimental values. The shift is direct proportional to the CR. Therefore the model can be considered as a semiquantitative one.

In Figure 5 the influence of polarization on the IFT can be seen in the aluminium/cryolite alumina melts, with and without $\mathrm{Na}_{2} \mathrm{SO}_{4}$. The systems were investi- 


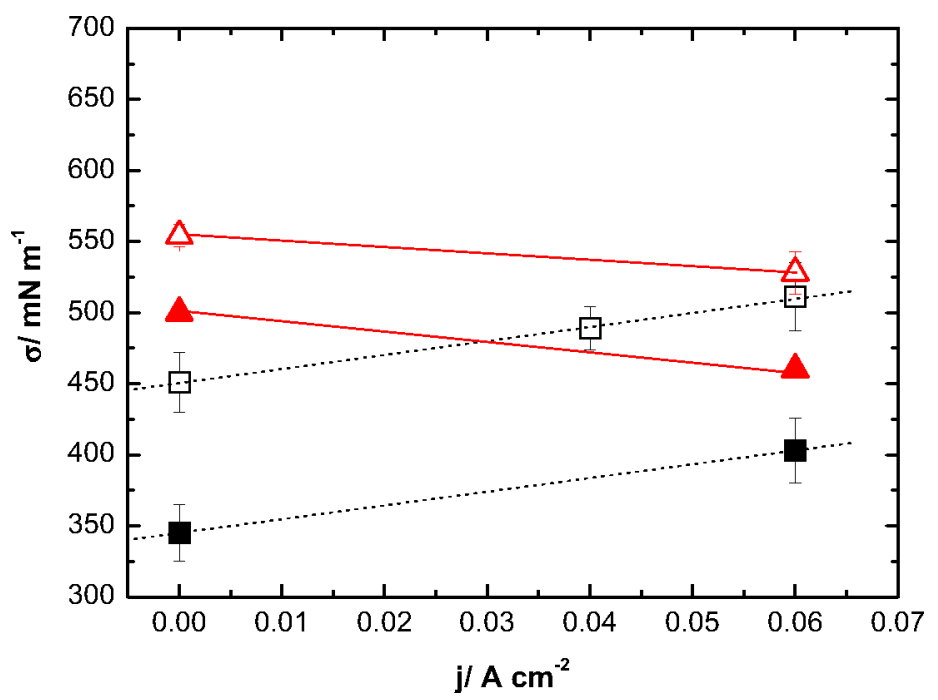

Fig. 5. Interfacial tension under the condition of electrolysis, i.e. interfacial tension as function of current. $\mathbf{\square}, \mathrm{Na}_{3} \mathrm{AlF}_{6}+\mathrm{NaF}+10 \mathrm{wt} \%$ $\mathrm{Al}_{2} \mathrm{O}_{3}+3.76$ wt. $\% \quad \mathrm{Na}_{2} \mathrm{SO}_{4} / \mathrm{Al}, \quad \mathrm{CR}=$ 3.63; $\square, \quad \mathrm{Na}_{3} \mathrm{AlF}_{6}+\mathrm{NaF}+10 \quad$ wt $\%$ $\mathrm{Al}_{2} \mathrm{O}_{3}+4.69$ wt. $\% \quad \mathrm{Na}_{2} \mathrm{SO}_{4} / \mathrm{Al}, \quad \mathrm{CR}=$ $2.29 ; \boldsymbol{\Lambda}, \mathrm{Na}_{3} \mathrm{AlF}_{6}+\mathrm{NaF}+10 \mathrm{wt} \% \mathrm{Al}_{2} \mathrm{O}_{3} / \mathrm{Al}$, $\mathrm{CR}=3.63 ; \triangle, \mathrm{Na}_{3} \mathrm{AlF}_{6}+\mathrm{NaF}+10 \mathrm{wt} \%$ $\mathrm{Al}_{2} \mathrm{O}_{3} / \mathrm{Al}, \mathrm{CR}=2.29$; all curves are linear formal lines. gated after 15 min electrolysis at each current density. The applied current has different influence on the investigated systems. In the systems without $\mathrm{Na}_{2} \mathrm{SO}_{4}$ the IFT decreases with increasing current density, and vice versa in systems with $\mathrm{Na}_{2} \mathrm{SO}_{4}$. These results are very interesting.

The IFT in the cryolite systems is strongly depending on the CR [1,2] and applied current [12]. The current is transported in a Hall-Héroult process mainly by $\mathrm{Na}^{+}$ions, and the aluminium cathode in this process is almost completely non-polarized. The result of the ionic migration of sodium cations is the rising of the concentration gradient of the hypothetical $\mathrm{NaF}$ species near the cathode. This concentration gradient decreases the IFT between the electrolyte and the molten aluminium cathode. However, the present sulphur-containing systems have a different behaviour under the same conditions.

Let us present the possible behaviour of sulphur species during the electrolysis. The observed data can be explained in the first step (without current conditions) by the model based on the reactions (1) and (2). The result of these reactions is the increase of the concentration of $\mathrm{NaF}$ species in the bulk of the elec-

[1] K. Grjotheim, C. Krohn, M. Malinovský, K. Matiašovský, and $\mathrm{J}$. Thonstad, Aluminium Electrolysis. Fundamentals of the Hall-Héroult Process, Aluminium-Verlag, Düsseldorf 1982.

[2] J. Thonstad, P. Fellner, G. M. Haarberg, J. Híveš, H. Kvande, and A. Sterten, Aluminium Elec- trolyte, and the increase of the CR. The higher concentration of $\mathrm{NaF}$ leads to the decrease of the IFT in the metal/electrolyte interface.

Applying of current also influences the interface. Probably it is caused by electrochemical deposition of some kind of sulphur-active species on the metal/electrolyte interface. The result of this electrochemical interaction is the subsequent increase of the IFT. The electrochemical deposition of sulphur-active species on the interface has a stronger influence on the IFT than the opposite influence of CR shift, caused only by concentration gradients of $\mathrm{NaF}$ near the cathode.

It has to be mentioned, however, that this explanation is more or less speculative. We have no other experimental evidence for such a behaviour of sulphur species in the cryolite melts under the condition of electrolysis.

\section{Acknowledgements}

This work was supported by the Science and Technology Assistance Agency under contract No. APVV -51-008104, and by the Slovak Grant Agency VEGA (2/4071/04).

trolysis, $3^{\text {rd }}$ ed., Aluminium-Verlag, Düsseldorf 2000.

[3] E. A. Zhemchuzhina and A. I. Belyaev, Fiz. Khim. Rasplav. Solei i Shlakov, Akad. Nauk SSSR, Uralsk. Filial, Inst. Elektrokhim., Tv. Vses. Saveshch., Sverdlovsk 1960 (cited in [1]). 
[4] A. D. Gerasimov and A. I. Belyaev, Izv. Vyssh. Ucheb. Zaved., Tsvet. Met. 1, 50 (1958) (cited in [1]).

[5] A. Portevin and P. Bastien, Met. Ind. 48, 716 (1955) (cited in [1]).

[6] A. I. Belyaev, Elektrolit alyuminievykh vann, Metalurgizdat, Moscow 1961 (cited in [1]).

[7] E. W. Dewing and P. Desclaux, Metall. Trans. B 8, 555 (1977).

[8] T. Utigard and J. M. Toguri, Metall. Trans. B 16, 333 (1985).

[9] T. Utigard and J. M. Toguri, Metall. Trans. B 17, 547 (1986).

[10] K. Grjotheim, H. Kvande, Qiu Zhu-Xian, and Fan Liman, Aluminium 65, 157 (1989).

[11] Z. Fan and T. Østvold, Aluminium 67, 287 (1991).

[12] M. Korenko and M. Ondercin, J. Appl. Electrochem. 36, 1347 (2006).

[13] K. Tveito, J. Tonheim, K. A. Paulsen, and J. Thonstad, Greenhouse Gases in the Metallurgical Industries, The Conference of Metallurgists, COM 2001, August $26-$ 29, Toronto, pp. $291-300$.

[14] J. Híveš, P. Fellner, M. Ambrová, and M. Korenko, The International Jomar Thonstad Symposium, October 16-18, 2002, Trondheim, Norway, pp. 153-159.

[15] S.H. Hay, M. M. Hyland, J. B. Metson, and O. M. Bade, $11^{\text {th }}$ Slovak-Norwegian Symposium on Aluminium Electrowinning, September 19-22, 2001, Trondheim, Norway, pp. $231-241$.

[16] P. Fellner, M. Ambrová, J. Híveš, M. Korenko, and J. Thonstad, Light Metals (Ed. H. Kvande), TMS (The
Minerals, Metals \& Materials Society), San Francisco 2005, pp. $577-581$.

[17] Y. V. Baimakov and M. M. Vetyukov, Molten Salts Electrolysis, Metallurgiya, Moscow 1966, pp. 410412 (in Russian).

[18] M. B. Shvartsberg, Trudy VAMI 14, 113 (1937) [cited according to: G. A. Abramov et al., Theoretical Principles of the Electrometallurgy of Aluminium, Metallurgizdat, Moscow 1953, p. 556 (in Russian)].

[19] M. Ambrová, P. Fellner, J. Gabčová, and A. Sýkorová, Chem. Pap. 59, 235 (2005).

[20] V. V. Burnakin, V. M. Mozhaev, V. A. Kryukovskiy, P. V. Polyakov, and S. N. Schipok, Izv. Vuzov. Tsvetnaya Metallurgiya 6, 46 (1982) (cited in [19]).

[21] V. V. Burnakin, R. K. Popkova, V. I. Zalivnoy, P. V. Polyakov, and V.I. Kolosova, Sov. Non-Ferrous Met. Res. 84, 282 (1983) (cited in [19]).

[22] I. T. Gul'din and A. V. Buzhinskaya, Elektrokhimiya 1, 716 (1965) (cited in [19]).

[23] M. Ambrová, V. Danielikír, P. Fellner, and J. Thonstad, Electrochim. Acta 51, 5825 (2006).

[24] M. Ambrová, Thesis, FCHPT STU Bratislava, Slovakia 2006 (in Slovak).

[25] G. P. Gilmore and V. L. Bullough, Light Metals (Ed. J. E. Andersen), TMS (The Minerals, Metals \& Materials Society), Dallas 1982, pp. $741-752$.

[26] A. F. LaCamera, S. P. Ray, X. Liu, R. L. Kozarek, and J. L. Roddy, Patent application, International Publication No. WO 2004/013380A1, 2004.

[27] A. Silný and T. A. Utigard, J. Chem. Eng. Data 41, 1340 (1996). 